\title{
PENGARUH KECUKUPAN MODAL, RISIKO DAN EFISIENSI TERHADAP KINERJA KEUANGAN BANK SEBELUM DAN MASA PANDEMI COVID-19
}

\author{
Rosmita Rasyid ${ }^{1}$, Herni Kurniawati \\ ${ }^{1}$ Program Studi Akuntansi, Universitas Tarumanagara Jakarta \\ Email: rosmitar@fe.untar.ac.id \\ ${ }^{2}$ Program Studi Akuntansi, Universitas Tarumanagara, Jakarta \\ Email:hernik@fe.untar.ac.id
}

\begin{abstract}
This study aims to examine the effect of covid 19 on financial performance and the factors that are thought to influence it, namely capital adequacy, risk and efficiency. The study was conducted on banking companies listed on the Indonesia Stock Exchange (IDX) in the period 2019 and 2020. The sample was determined using the purposive method. sampling, in order to obtain a total sample of 21 banking companies. The method used is to perform a mean difference test and multiple regression analysis with the fixed effect model (FEM). The results of this study show that the average ROA, CAR, NPL, LDR and BOPO before covid with during covid are significantly different, the results of multiple regression show that LDR has a positive effect on ROA and BOPO has a negative effect on ROA while CAR and NPL have no effect on ROA.
\end{abstract}

Keywords: Capital Adequacy, Risk, Efficiency, Bank Financial Performance, Covid-19

\section{ABSTRAK}

Penelitian ini bertujuan untuk menguji pengaruh covid 19 atas kinerja keuangan serta faktor yang diduga mempengaruhinya yakni kecukupan modal, risiko dan efisiensi.Penelitian dilakukan pada perusahaan perbankan yang terdafrat di Bursa Efek Indonesia (BEI) pada periode 2019 dan 2020. Sampel ditentukan dengan menggunakan metode purposive sampling, sehingga diperoleh jumlah sampel sebanyak 21 perusahaan perbankan. Metode yang digunakan adalah dengan melakukan uji beda rata-rata dan analisis regresi berganda dengan fixed effect model (FEM). Hasil penelitian ini menunjukkan rata-rata $R O A, C A R, N P L, L D R$ dan BOPO sebelum covid dengan selama covid adalah berbeda signikan, Hasil regresi berganda memperlihatkan bahwa $L D R$ berpengaruh positf terhadap $R O A$ dan BOPO berpengaruh negatif terhadap $R O A$ sedangkan $C A R$, dan NPL tidak berpengaruh terhadap $R O A$

Kata Kunci: Kecukupan Modal, Risiko, Efisiensi, Kinerja Keuangan Bank, Covid-19

\section{PENDAHULUAN}

\section{Latar Belakang}

Kondisi pandemi covid-19 yang masih menghantui dunia telah membawa dampak pada kehidupan penduduk dunia termasuk di Indonesia. Covid yang berawal dari Wuhan, China pada November 2019 itu telah diakui keberadaannya di Indonesia pada bulanMaret 2020.

Munculnya bencana covid-19 telah menimbulkan pengaruh merugikan bagi banyak dunia usaha di Indonesia. Dunia usaha mengalami tantangan amat berat. Sekitar setengah dari 3,3 miliar pekerja di dunia menghadapi risiko kekurangan uang dan atau kehilangan pekerjaan dalam berbagai tingkatannya. Sektor ekonomi informal juga terpukul hebat, IMF memperingatkan bahwa pandemi covid-19 akan menyebabkan krisis ekonomi berkepanjangan (https://internasional.kontan.co.id/news/imf-peringatkan-ancaman-krisis-ekonomiberkepanjangan-akibat-pandemi-covid). Hal ini selanjutnya akan mempengaruhi kinerja keuangan dunia usaha termasuk dunia perbankan.

Kinerja perbankan terpuruk akibat pandemi coronavirus bikin bank makin terseok(https://keuangan.kontan.co.id/news/begini-nasib-industri-perbankan-di-saat-pandemivirus-corona-covid-19, Selasa 20 Oktober 2020). Pertumbuhan kredit perbankan hanya 1,5\% dibandingkan dengan tahun lalu. https://www.okezone.com/tren/read/2020/09/24/620/2282901 
Banyak faktor yang dapat mempengaruhi kinerja keuangan bank. Faktor pertama adalah kecukupan modal atau yang lebih dikenal dengan istilah CAR (Capital Adequacy Ratio).CAR berfungsi menampung risiko kerugian yang kemungkinan akan dihadapi oleh bank. Semakin tinggi capital adequacy ratio maka akan semakin baik pula kemampuan bank dalam menghadapi risiko yang mungkin terjadi. Menurut Otoritas Jasa Keuangan (OJK) telah terjadi penurunan capital adequacy ratio perbankan menjadi $21.72 \%$ pada kuartal 1/2020.

Terdapat hasil penelitian yang berbeda atas faktor-faktor yang mempengaruhi kinerja keuangan perbankan. Ikhtikar dan Mubbushar (2016) menemukan bahwa terdapat pengaruh positif rasio kecukupan modal atau CAR terhadap kinerja keuangan, namun Isanzu (2017) menemukan hubungan yang berkebalikan yakni $C A R$ perpengaruh negatif terhadap kinerja keuangan. Aspal dkk (2019) menemukan bahwa $C A R$ tidak berpengaruh terhadap kinerja keuangan.

Secara umum risiko yang dihadapi bank dapat berupa risiko kredit maupun risiko likuiditas. Risiko kredit tercermin dalam non performing loan. Non performingloan merupakan kredit bermasalah yang menjadi salah satu kunci untuk menilai kualitas kinerja bank. Kredit bermasalah adalah total keseluruhan kredit yang berada dalam kolektibilitas kredit kurang lancar, diragukan, dan macet.

Berdasarkan hasil penelitian Iftikar dan Mubbushar (2016) $\mathrm{npl}$ berpengaruh positif terhadap kinerja keuangan. Isanzu (2017) menemukan bahwa $n p l$ berpengaruh negatif terhadap kinerja keuangan, namun Buchory (2015) tidak menemukan pengaruh $n p l$ terhadap kinerja keuangan.

Risiko likuiditas tercermin dari loan to deposit ratio yaitu rasio yang mengukur komposisi jumlah kredit yang diberikan dibandingkan dengan jumlah dana pihak ketiga berupa giro, tabungan, dan deposito. Standar loan to deposit ratiomenurut Bank Indonesia berada diantara $80 \%-110 \%$.

Hasil penelitian Buchory (2015) menunjukkan $l d r$ tidak berpengaruh terhadap kinerja keuangan, namun hasil penelitian Syaiful dan Ayu (2019) menemukan bahwa $l d r$ berpengaruh positif terhadap kinerja keuangan.

Efisiensi bank dalam beroperasi tercermin dari biaya operasional per pendapatan operasional (BOPO) bank tersebut. Apabila semakin kecil BOPO berarti bank semakin efisien sehingga akan meningkatkan kinerja keuangan bank.

Menurut hasil penelitian Syaiful dan Ayu (2019) menunjukkan bahwa efisiensi operasional berpengaruh positif terhadap kinerja keuangan. Hasil sebaliknya ditemukan oleh Aspal, dkk (2019) yang menunjukkan bahwa efisiensi operasional berpengaruh negatif terhadap kinerja keuangan.

Berdasarkan penelitian-penelitian yang dilakukan terdahulu, terdapat ketidaksesuaian dari hasil penelitian satu dan yang lainnya mengenai faktor-faktor yang mempengaruhi kinerja keuangan bank. Munculnya krisis karena covid 19 semakin menambah masalah. Oleh karena itu penelitian menarik dilakukan untuk menguji pengaruh risiko kredit, risiko likuiditas dan efisiensi terhadap kinerja keuangan pada perusahaan perbankan yang terdaftar di Bursa Efek Indonesia sebelum dan dimasa covid 19.

\section{METODE PENELITIAN}

Desain penelitian ini adalah desain penelitian deskriptif. Data yang digunakan dalam penelitian ini adalah data perusahaan-perusahaan Perbankan yang telah terdaftar dalam Bursa Efek Indonesia (BEI) pada periode sebelum covid 19 dan dimasa covid 19.Penelitian ini terdiri dari variabel dependen dan variabel independen. Variabel dependennya adalah ROA yang mencerminkan kinerja keuangan dan variabel independen terdiri dari $C A R$ yang mencerminkan kecukupan modal, NPL mencerminkan risiko kredit, $L D R$ mencerminkan risiko likuiditas dan BOPO mencerminkan efisiensi. 
Populasi dalam penelitian ini adalah perusahaan perbankan yang terdaftar dalam Bursa Efek Indonesia (BEI) pada periode sebelum covid 19 dan dimasa covid 19. Data untuk periode sebelum covid diambil dari data Laporan Tahunan yang berakhir 31 Desember 2019 dan periode dimasa covid diambil dari data Laporan Tahunan yang berakhir 31Desember 2020.

Metode yang digunakan dalam teknik pemilihan sampel pada penelitian ini adalah purposive sampling karena teknik penarikan sampel yang digunakan dapat disesuaikan dengan tujuan penelitian yang didasarkan atas batasan kriteria-kriteria yang dibentuk dengan berbagai pertimbangan. Berikut adalah kriteria-kriteria pemilihan sampel dalam penelitian ini:

a. Perusahaan perbankan yang telah terdaftar di Bursa Efek Indonesia (BEI) pada periode sebelum covid 19 yakni 2019 dan dimasa covid 19 yakni 2020.

b. Perusahaan perbankan yang memilikilaporan keuangan dengan menggunakan mata uang Rupiah (IDR).

c. Perusahaan perbankan yang memiliki data yang lengkap.

Penelitian ini terdiri dari variabel dependen dan variabel independen. Pada uji beda variabel dependennya adalah kinerja keuangan dimasa covid 19 (Y) yakni 2020 dan variabel independennya adalah kinerja keuangan sebelum covid 19 (X) yakni 2019.

Pada uji regresi berganda variabel dependennya adalah kinerja keuangan (Y), dan variabel independennya terdiri dari kecukupan modal yang diproksikan dengan Return on Total Asset $\left(X_{1}\right)$, risiko terdiri dari risiko kredit yang diproksikan dengan Non Performing Loan (X2) dan risiko likuiditas yang diproksikan dengan Loan to deposit ratio (X3), dan Efisiensi yang diproksikan dengan Beban Operasional Pendapatan .( $\left.\mathrm{X}_{4}\right)$. Operasionalisasi variabel dapat pada tabel 1 di bawah ini.

Tabel 1. Tabel Operasionalisasi Variabel

\begin{tabular}{llll}
\hline No. & \multicolumn{1}{c}{ Variabel } & \multicolumn{1}{c}{ Cara Pengukuran } & Skala \\
\hline 1. & Kinerja Keuangan & $R O A=\frac{\text { Laba Bersih Setelah Pajak }}{\text { Total Aset }}$ & Rasio \\
\hline 2. & Kecukupan Modal & $C A R=\frac{\text { Modal Inti+Modal Pelengkap }}{\text { Aktiva Tertimbang Menurut Risiko }}$ & Rasio \\
\hline 3. & Risiko kredit & $N P L=\frac{\text { Kredit Bermasalah }}{\text { Total Kredit }}$ & Rasio \\
\hline 4. & Risiko likuiditas & $L D R=\frac{\text { Total Kredit yang Diberikan }}{\text { Total Dana Pihak Ketiga }}$ & Rasio \\
\hline 5. & Efisiensi & $B O P O=\frac{\text { Biaya Operasional }}{\text { Pendapatan Operasional }}$ & Rasio \\
\hline
\end{tabular}

\section{HASIL DAN PEMBAHASAN}

Penelitian ini memiliki tujuan untuk melihat apakah ada perbedaan kinerja keuangan, kecukupan modal, risiko kredit, risiko likuiditas, dan efisiensi bank dimasa covid 19 dan kinerja keuangan bank, kecukupan modal, risiko kredit, risiko likuiditas, dan efisiensi sebelum covid 19. Penelitian ini juga bertujuan untuk melihat faktor-faktor yang mempengaruhi kinerja keuangan. Perusahaan yang diteliti adalah perusahaan perbankan yang terdaftar dalam Bursa Efek Indonesia (BEI) pada periode sebelum covid 19 dan dimasa covid 19. Data sebelum covid 19 diambil dari laporan keuangan tahunan 2019 dan dimasa covid diambil dari data laporan tahunan 2020 . Terdapat 46 perusahaan perbankan yang terdaftar di BEI, namun yang telah mempublikasikan laporan tahunan 2020 sampai dengan minggu pertama bulan Juni 2021 hanyalah 21 perusahaan 
perbankan. Berdasarkan hal ini maka sampel yang digunakan dalam penelitian ini hanyalah 21 perusahaan perbankan selama dua tahun yang menghasilkan 42 observasi.

Tabel 2. Statistik Data Deskriptif 2019-2020

\begin{tabular}{lcccccc}
\hline & ROA & CAR & NPL & LDR & BOPO & DCOVID \\
\hline Mean & 0.012740 & 0.245398 & 0.019176 & 0.901638 & 0.826902 & 0.500000 \\
\hline Median & 0.013500 & 0.215150 & 0.015250 & 0.863100 & 0.840900 & 0.500000 \\
\hline Maximum & 0.040000 & 0.539800 & 0.049600 & 1.630000 & 1.168400 & 1.000000 \\
\hline Minimum & -0.018700 & 0.162000 & 0.004000 & 0.496000 & 0.336000 & 0.000000 \\
\hline Std. Dev. & 0.013353 & 0.088865 & 0.013214 & 0.247118 & 0.164601 & 0.506061 \\
\hline Skewness & 0.090166 & 1.727283 & 0.793504 & 1.332115 & -0.708001 & 0.000000 \\
\hline Kurtosis & 2.655584 & 5.268900 & 2.577695 & 4.874852 & 3.759204 & 1.000000 \\
\hline \multicolumn{7}{c}{0} \\
Jarque-Bera & 0.264497 & 29.89340 & 4.719640 & 18.57308 & 4.517545 & 7.000000 \\
\hline Probability & 0.876123 & 0.000000 & 0.094437 & 0.000093 & 0.104479 & 0.030197 \\
\hline \multicolumn{7}{c}{0} \\
\hline Sum & 0.535100 & 10.30670 & 0.805400 & 37.86880 & 34.72990 & 21.00000 \\
\hline Sum Sq. Dev. & 0.007311 & 0.323778 & 0.007159 & 2.503768 & 1.110835 & 10.50000 \\
\hline \multicolumn{7}{c}{40} \\
\hline Observations & 42 & 42 & & & 42 \\
\hline
\end{tabular}

Statistik deskriptif penelitian ini pada tabel 2 memperlihatkan $R O A$ memiliki rata-rata 1,274\% dalam periode 2019-2020, dengan nilai maksimum 4\% yang terdapat pada Bank BCA tahun 2019, sedangkan nilai minimum -0,187\% yang terdapat pada Bank Harda International.

CAR memiliki rata-rata $24,54 \%$ dalam periode $2019-2020$, dengan nilai maksimum $53,98 \%$ yang terdapat pada bank Dinar tahun 2020, sedangkan nilai minimum 16,2\% yang terdapat pada bank Harda International tahun 2019. NPL. memiliki rata-rata 1,92\% dalam periode 2019-2020, dengan nilai maksimum $4,96 \%$ yang terdapat pada bank Victoria tahun 2020, sedangkan nilai minimum 0,4\% yang terdapat pada bank BTPN tahun 2019.

LDR memiliki rata-rata $90,16 \%$ dalam periode $2019-2020$, dengan nilai maksimum $163 \%$ yang terdapat pada bank BTPN tahun 2019, sedangkan nilai minimum 49,6\% yang terdapat pada bank Artha Graha International tahun 2020 .

BOPO memiliki rata-rata 82,69\% dalam periode 2019-2020, dengan nilai maksimum 116,84\% yang terdapat pada bank Harda International tahun 2020, sedangkan nilai minimum 33,6\% yang terdapat pada bank QNB tahun 2019.

Mean ROA tahun 2019 sebesar 1,3 dan tahun 2020 1,27. Mean CAR tahun 2019 sebesar 469,7, dan 2020 sebesar 519,87, Mean NPL tahun 2019 sebesar 2,03 dan tahun 2020 sebesar 1,8. Mean LDR tahun 2019 sebesar 93,67 dan tahun 2020 sebesar 86,65. Mean BOPO tahun 2019 sebesar 80,53 dan tahun 2020 sebesar 81,083.

Hasil uji beda mean berdasarkan tabel 4, 5, 6 dan 7 pada lampiran memperlihatkan hasil uji beda rata-rata (mean) ROA, CAR, NPL, LDR dan BOPO pada periode sebelum covid 19 berbeda secara signifikan dengan masa covid 19. Hal ini memberi indikasi bahwa pandemi covid 19 telah mengubah rata-rata (mean) ROA, CAR, NPL, LDR dan BOPO perusahaan perbankan secara signifikan.

Hasil regresi setelah melalui uji Chow dan dilanjutkan dengan uji Hausman menunjukkan model yang fit digunakan adalah fixed effect model, yang terlihat dalam tabel 3 di bawah ini. 
Tabel 3. Hasil Regresi dengan Fixed Effect Model

Dependent Variable: ROA

Method: Panel EGLS (Cross-section weights)

Date: 06/17/21 Time: 22:08

Sample: 20192020

Periods included: 2

Cross-sections included: 21

Total panel (balanced) observations: 42

Linear estimation after one-step weighting matrix

\begin{tabular}{crrrr}
\hline \hline Variable & Coefficient & Std. Error & t-Statistic & Prob. \\
\hline \hline C & 0.072715 & 0.006254 & 11.62752 & 0.0000 \\
CAR & 0.001257 & 0.005500 & 0.228508 & 0.8221 \\
NPL & -0.058650 & 0.033319 & -1.760252 & 0.0975 \\
LDR & 0.011901 & 0.003444 & 3.455495 & 0.0033 \\
BOPO & -0.084736 & 0.005455 & -15.53343 & 0.0000 \\
DCOVID & 0.000361 & 0.000520 & 0.693988 & 0.4976 \\
\hline \hline
\end{tabular}

Cross-section fixed (dummy variables)

\begin{tabular}{llll}
\hline \hline & \multicolumn{2}{l}{ Weighted Statistics } & \\
\hline \hline R-squared & 0.998620 & Mean dependent var & 0.064136 \\
Adjusted R-squared & 0.996463 & S.D. dependent var & 0.107828 \\
S.E. of regression & 0.004060 & Sum squared resid & 0.000264 \\
F-statistic & 463.0376 & Durbin-Watson stat & 2.818182 \\
Prob(F-statistic) & 0.000000 & & \\
\hline \hline & Unweighted Statistics & \\
\hline \hline & 0.914848 & Mean dependent var & 0.012740 \\
R-squared & 0.000623 & Durbin-Watson stat & 2.818182 \\
\hline \hline
\end{tabular}

Analisis regresi linier berganda dengan fixed effect model terlihat dalam tabel 3 . Data penelitian telah terdistribusi secara normal seperti terlihat dalam Gambar 1 pada lampiran dan penelitian ini telah bebas dari multikolinearitas seperti terlihat dalam tabel 8 pada lampiran, bebas dari heteroskedastitas seperti terlihat dalam tabel 9 pada lampiran dan bebas autokorelasi.terlihat dalam tabel 3.

Berdasarkan hasil analisis persamaan regresi dalam tabel 3 diperoleh persamaan regresi sebagai berikut:

$$
R O A=0,0727+0,0013 C A R-0,0586 N P L+0,0119 L D R-0,0847 \mathrm{BOPO}+0,0036 \mathrm{DV}+\varepsilon
$$

Berdasarkan tabel 3 terlihat bahwa kecukupan modal yang diproksikan dengan $C A R$ menunjukkan hasil positif namun tidak signifikan terhadap kinerja keuangan yang diproksikan dengan ROA. Ini berarti bahwa kecukupan modal yang diproksikan dengan $C A R$ tidak berpengaruh terhadap kinerja keuangan yang diproksikan dengan $R O A$, sehingga $\mathrm{H}_{1}$ ditolak. Ini menunjukkan bahwa kenaikan rata-rata $C A R$ di tahun 2020 dibanding tahun 2019, belum mampu meningkatkan $R O A$ perbankan. Peningkatan $C A R$ mengindikasikan bahwa bank meningkatkan basis modal dalam mengantisipasi penyerapan kerugian tak terduga yang berpotensi timbul dari risiko pandemi covid 19 terhadap industri perbankan dan bukan dalam rangka memperbesar laba. 
Resiko kredit yang diproksikan dengan $N P L$ menunjukkan hasil negatif namun tidak signifikan terhadap kinerja keuangan yang diproksikan dengan $R O A$. Ini berarti bahwa risiko kredit yang diproksikan dengan NPL tidak berpengaruh terhadap kinerja keuangan yang diproksikan dengan $R O A$, sehingga $\mathrm{H}_{2}$ ditolak. Ini menunjukkan bahwa rata-rata $N P L$ di tahun 2020 dibanding tahun 2019, belum mampu meningkatkan ROA perbankan. NPL tidak berpengaruh terhadap ROA. Mean NPL yang menurun ditahun 2020 dibanding tahun 2019 mengindikasikan perbankan mengikuti kebijakan Otoritas Jasa Keuangan mengenai mengeluarkan kebijakan pokok ditengah pandemi demi mendukung usaha sekaligus sektor perbankan yang tertuang dalam POJK No. 11/POJK.03/2020 tentang Stimulus Perekonomian sebagai Kebijakan Countercyclical Dampak Penyebaran Coronavirus Disease 2019 di industri perbankan.

$L D R$ terlihat dalam tabel 3 menunjukkan hasil positif signifikan terhadap $R O A$. Ini menunjukkan bahwa risiko likuiditas yang diproksikan dengan $L D R$ mempengaruhi kinerja keuangan yang diproksikan dengan $R O A$, sehingga $\mathrm{H}_{3}$ diterima. Penelitian ini hasilnya sejalan dengan hasil penelitian Aspal (2019) yang menemukan bahwa $L D R$ berpengaruh positif terhadap ROA. Hal ini membuktikan bahwa kenaikan kinerja keuangan yang diproksikan dengan $R O A$ memang dipicu salah satunya oleh kenaikan risiko likuiditas yang diproksikan dengan $L D R$.

BOPO terlihat dalam tabel 3.menunjukkan hasil signifikan negatif terhadap ROA. Semakin kecil nilai BOPO maka hal ini berarti semakin efisien operasional perbankan. Ini menunjukkan bahwa efisiensi yang diproksikan oleh BOPO yang bernilai negatif yang berarti efisiensi operasional bank bernilai positif mempengaruhi kinerja keuangan yang diproksikan dengan $R O A$, artinya semakin efisien operasional bank maka semakin meningkat kinerja keuangan sehingga $\mathrm{H}_{4}$ diterima. Penelitian ini hasilnya sejalan dengan hasil penelitian Dewi dan Bajra (2020) yang menemukan bahwa BOPO berpengaruh negatif terhadap ROA.

Variabel dummy Covid-19 (DV) menunjukkan hasil positif namun tidak signifikan terhadap ROA. Ini berarti variabel dummy covid-19 tidak berpengaruh terhadap kinerja keuangan perbankan.Dapat disimpulkan bahwa kondisi pandemi covid-19 tidak berpengaruh terhadap kinerja keuangan perbankan. Hal ini kemungkinan terjadi karena pada masa pandemi bank telah menyesuaikan diri dengan kelonggaran yang diberikan perbankan mengikuti kebijakan Otoritas Jasa Keuangan mengenai mengeluarkan kebijakan pokok ditengah pandemi demi mendukung usaha sekaligus sektor perbankan yang tertuang dalam POJK No. 11/POJK.03/2020 tentang Stimulus Perekonomian sebagai Kebijakan Countercyclical Dampak Penyebaran Coronavirus Disease 2019 di industri perbankan.

\section{KESIMPULAN}

Kesimpulan dari penelitian ini adalah sebagai berikut:

a. Terdapat perbedaan rata-rata (mean) ROA, CAR, NPL, LDR dan BOPO sebelum covid 19 dengan dimasa covid 19 secara signifikan..

b. Kecukupan modal yang diproksikan dengan $C A R$ tidak berpengaruh terhadap kinerja keuangan yang diproksikan dengan $R O A$.

c. Risiko kredit yang diproksikan dengan $N P L$ tidak berpengaruh terhadap kinerja keuangan yang diproksikan dengan $R O A$.

d. Risiko likuiditas yang diproksikan dengan $L D R$ berpengaruh positif terhadap kinerja keuangan yang diproksikan dengan $R O A$.

e. Efisiensi yang diproksikan dengan BOPO terhadap kinerja keuangan yang diproksikan dengan ROA berpengaruh negatif atau makin menurun BOPO maka makin efisien, sehingga efisiensi berpengaruh positif terhadap kinerja keuangan.

Variabel dummy covid-19 tidak berpengaruh terhadap kinerja keuangan perbankan

Keterbatasan penelitian ini adalah: 
a. Belum semua bank mempublikasikan laporan keuangan dan laporan tahunan untuk tahun 2020. Diharapkan penelitian selanjutnya dapat menggunakan data yang lebih lengkap.

b. Variabel yang diteliti hanya $C A R, N P L, L D R$ dan BOPO terhadap ROA. Diharapkan penelitian selanjutnya menggunakan variabel yang lebih banyak.

c. Tahun yang digunakan sebelum covid adalah tahun 2019 dan masa covid 2020. Diharapkan penelitian selanjutnya dapat memperpanjang periode penelitian

\section{Ucapan Terima Kasih}

Ucapan terima kasih kami haturkan kepada pihak-pihak yang memudahkan kami menyelesaikan tugas PKM ini terutama kepada LPPM Untar.

\section{REFERENSI}

Ajija dkk (2019). Cara Cerdas Menguasai Eviews. Jakarta: Salemba Empat

Aspal, P. K., Dhawan, S., \& Nazneen, A. (2019). Significance of Bank Specific and Macroeconomic Determinants on Performance of Indian Private Sector Banks. International Journal of Economics and Financial Issues, 9(2), 168.

Brigham, E., \& Houston, J. (2018). Fundamentals of Financial Management, Concise Eight Edition. Mason: South-Western Cengange Learning.

Buchory, A. H. (2015). Banking Intermediation, Operational Efficiency and Credit Risk in The Banking Profitability. Proceeding- Kuala Lumpur International Business, Economics and Law Conference 7, 2(1), 51.

Iftikhar, M. (2016). Impact of Credit Risk Management on Financial Performance of Commercial Banks of Pakistan. University of Haripur Journal of Management (UOHJM), 1(2), 110-125.

Isanzu, S. J. (2017). The Impact of Credit Risk on the Financial Performance of Chinese Banks. Journal of International Business Research and Marketing, 2(3), 14-17.

POJK No. 11/POJK.03/2020

Saiful, S., \& Ayu, D. P. (2019). Risks Management and Bank Performance: the Empirical Evidences From Indonesian Conventional and Islamic Banks. International Journal of Economics and Financial Issues, 9(4), 90-94.

www.idx.co.id 


\section{LAMPIRAN}

Tabel 4. UJI BEDA MEAN ROA MASA SEBELUM DAN MASA COVID

Test for Equality of Means of ROA

Categorized by values of ROA and DCOVID

Date: 06/17/21 Time: 21:07

Sample: 142

Included observations: 42

\begin{tabular}{lrrr}
\hline \hline Method & df & Value & Probability \\
\hline \hline Anova F-test & $(6,35)$ & 19.80072 & 0.0000
\end{tabular}

Analysis of Variance

\begin{tabular}{lrrr}
\hline \hline Source of Variation & df & Sum of Sq. & Mean Sq. \\
\hline \hline Between & 6 & 0.005647 & 0.000941 \\
Within & 35 & 0.001664 & $4.75 \mathrm{E}-05$ \\
\hline \hline Total & 41 & 0.007311 & 0.000178 \\
\hline \hline
\end{tabular}

Category Statistics

\begin{tabular}{cc|rrrr}
\hline \hline & & & & & Std. Err. \\
DCOVID & ROA & Count & Mean & Std. Dev. & $\begin{array}{r}\text { of Mean } \\
\hline 0\end{array}$ \\
\hline 0 & {$[0.02,0)$} & 3 & -0.008133 & 0.009152 & 0.005284 \\
0 & {$[0.02,0.04)$} & 11 & 0.007909 & 0.006514 & 0.001964 \\
0 & {$[0.04,0.06)$} & 6 & 0.028800 & 0.005902 & 0.002410 \\
1 & {$[-0.02,0)$} & 1 & 0.040000 & $N A$ & NA \\
1 & {$[0,0.02)$} & 2 & -0.006650 & 0.008132 & 0.005750 \\
1 & {$[0.02,0.04)$} & 15 & 0.010640 & 0.006914 & 0.001785 \\
1 & {$[0.04,0.06)$} & 4 & 0.028350 & 0.007355 & 0.003677 \\
& All & 0 & NA & NA & NA \\
\hline \hline
\end{tabular}

Tabel 5. UJI BEDA MEAN CAR MASA SEBELUM DAN MASACOVID

Test for Equality of Means of CAR

Categorized by values of CAR and DCOVID

Date: 06/17/21 Time: 21:23

Sample: 142

Included observations: 42

\begin{tabular}{lccc}
\hline \hline Method & df & Value & Probability \\
\hline \hline Anova F-test & $(8,33)$ & 126.3953 & 0.0000 \\
Analysis of Variance & & & \\
\hline \hline Source of Variation & df & Sum of Sq. & Mean Sq. \\
\hline \hline Between & 8 & 0.313545 & 0.039193 \\
Within & 33 & 0.010233 & 0.000310 \\
\hline \hline Total & 41 & 0.323778 & 0.007897 \\
\hline \hline
\end{tabular}


Category Statistics

\begin{tabular}{cc|rrrr}
\hline \hline & & & & & Std. Err. \\
DCOVID & CAR & Count & Mean & Std. Dev. & $\begin{array}{r}\text { of Mean } \\
\hline 0\end{array}$ \\
0 & {$[0.1,0.2)$} & 8 & 0.178313 & 0.012938 & 0.004574 \\
0 & {$[0.2,0.3)$} & 10 & 0.224170 & 0.015022 & 0.004750 \\
0 & {$[0.3,0.4)$} & 1 & 0.349000 & NA & NA \\
0 & {$[0.5,0.5)$} & 2 & 0.435250 & 0.031891 & 0.022550 \\
1 & {$[0.1,0.2)$} & 0 & NA & NA & NA \\
1 & {$[0.2,0.3)$} & 8 & 0.186450 & 0.012694 & 0.004488 \\
1 & {$[0.3,0.4)$} & 8 & 0.236325 & 0.019563 & 0.006916 \\
1 & {$[0.4,0.5)$} & 3 & 0.347367 & 0.033215 & 0.019177 \\
1 & {$[0.5,0.6)$} & 1 & 0.454900 & NA & NA \\
& All & 1 & 0.539800 & NA & NA \\
& & 42 & 0.245398 & 0.088865 & 0.013712
\end{tabular}

Tabel 6. UJI BEDA MEAN LDRMASA SEBELUM DANMASACOVID

Test for Equality of Means of LDR

Categorized by values of LDR and DCOVID

Date: 06/17/21 Time: 21:33

Sample: 142

Included observations: 42

\begin{tabular}{lccr}
\hline \hline Method & df & Value & Probability \\
\hline \hline Anova F-test & $(6,35)$ & 27.14133 & 0.0000 \\
Analysis of Variance & & & \\
\hline \hline Source of Variation & df & Sum of Sq. & Mean Sq. \\
\hline \hline Between & 6 & 2.060843 & 0.343474 \\
Within & 35 & 0.442925 & 0.012655 \\
\hline \hline Total & 41 & 2.503768 & 0.061068 \\
\hline \hline
\end{tabular}

Category Statistics

\begin{tabular}{cc|rrrr}
\hline \hline & & & & & Std. Err. \\
DCOVID & LDR & Count & Mean & Std. Dev. & $\begin{array}{r}\text { of Mean } \\
\hline 0\end{array}$ \\
\hline 0 & {$[0,0.5)$} & 0 & NA & NA & NA \\
0 & {$[1,1.5)$} & 17 & 0.844453 & 0.103065 & 0.024997 \\
0 & {$[1.5,2)$} & 3 & 1.227933 & 0.143412 & 0.082799 \\
1 & {$[0,0.5)$} & 1 & 1.630000 & NA & NA \\
1 & {$[0.5,1)$} & 1 & 0.496000 & NA & NA \\
1 & {$[1,1.5)$} & 17 & 0.795800 & 0.118082 & 0.028639 \\
1 & {$[1.5,2)$} & 2 & 1.275900 & 0.093480 & 0.066100 \\
\hline & All & 1 & 1.622900 & NA & NA \\
\hline \hline
\end{tabular}




\section{Tabel 7. UJI BEDA MEAN BOPOMASA SEBELUM DANMASACOVID}

Test for Equality of Means of BOPO

Categorized by values of BOPO and DCOVID

Date: 06/17/21 Time: 21:35

Sample: 142

Included observations: 42

\begin{tabular}{lrrr}
\hline \hline Method & df & Value & Probability \\
\hline \hline Anova F-test & $(8,33)$ & 31.92420 & 0.0000 \\
Analysis of Variance & & & \\
\hline \hline Source of Variation & df & Sum of Sq. & Mean Sq. \\
\hline \hline Between & 8 & 0.983726 & 0.122966 \\
Within & 33 & 0.127109 & 0.003852 \\
\hline \hline Total & 41 & 1.110835 & 0.027094 \\
\hline \hline
\end{tabular}

Category Statistics

\begin{tabular}{cc|rrrr}
\hline \hline DCOVID & BOPO & Count & Mean & Std. Dev. & $\begin{array}{r}\text { Std. Err. } \\
\text { of Mean }\end{array}$ \\
\hline 0 & {$[0.2,0.4)$} & 1 & 0.336000 & NA & NA \\
0 & {$[0.4,0.6)$} & 2 & 0.530200 & 0.085984 & 0.060800 \\
0 & {$[0.6,0.8)$} & 6 & 0.722600 & 0.031782 & 0.012975 \\
0 & {$[0.8,1)$} & 8 & 0.904825 & 0.062901 & 0.022239 \\
0 & {$[1,1.2)$} & 4 & 1.061000 & 0.074341 & 0.037171 \\
1 & {$[0.2,0.4)$} & 0 & $\mathrm{NA}$ & $\mathrm{NA}$ & $\mathrm{NA}$ \\
1 & {$[0.4,0.6)$} & 1 & 0.542000 & $\mathrm{NA}$ & $\mathrm{NA}$ \\
1 & {$[0.6,0.8)$} & 5 & 0.709240 & 0.059735 & 0.026714 \\
1 & {$[0.8,1)$} & 14 & 0.887157 & 0.065701 & 0.017559 \\
1 & {$[1,1.2)$} & 1 & 1.006900 & $\mathrm{NA}$ & $\mathrm{NA}$ \\
\hline & All & 42 & 0.826902 & 0.164601 & 0.025399
\end{tabular}

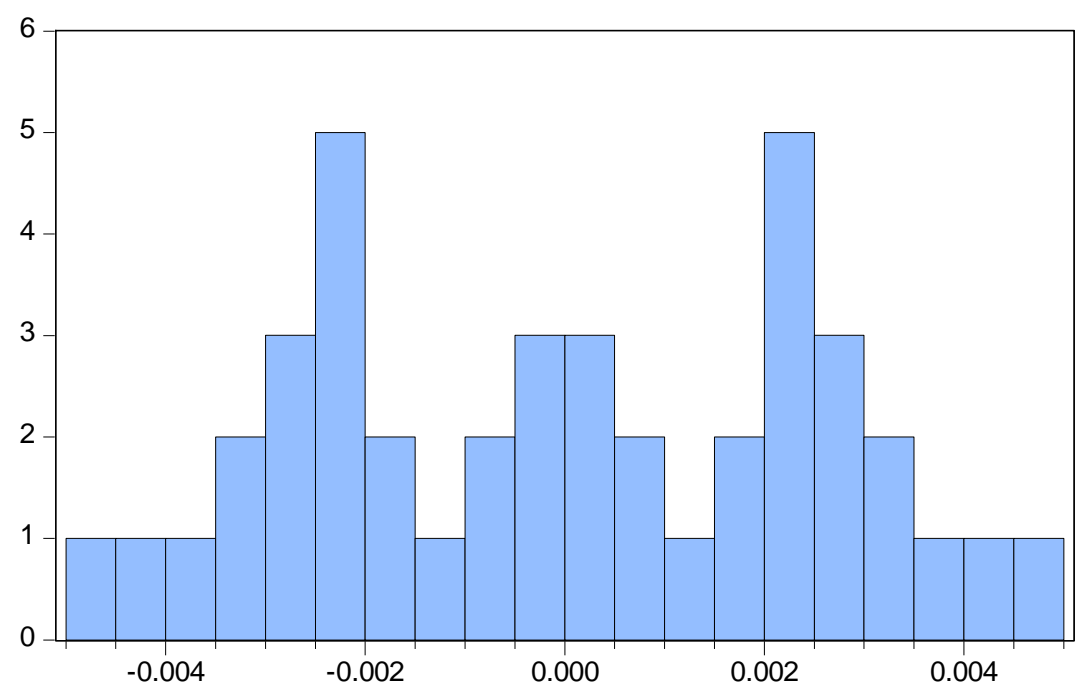

Gambar 1. HASIL UJI NORMALITAS RESIDUAL
Series: Standardized Residuals Sample 20192020

Observations 42

Mean $\quad-6.51 \mathrm{e}-19$

Median $\quad 0.000000$

Maximum $\quad 0.004756$

Minimum $\quad-0.004756$

Std. Dev. $\quad 0.002537$

Skewness $\quad 6.17 \mathrm{e}-16$

Kurtosis $\quad 1.856685$

Jarque-Bera $\quad 2.287544$

Probability $\quad 0.318615$ 
Tabel 8. KORELASI ANTAR INDEPENDEN VARIABEL

\begin{tabular}{|c|c|c|c|c|c|c|}
\hline & ROA & CAR & NPL & LDR & BOPO & DCOVID \\
\hline ROA & 1 & & & & & \\
\hline CAR & -0.1337329 & 1 & & & & \\
\hline NPL & -0.5574306 & 0.0380419 & 1 & & & \\
\hline LDR & -0.0110429 & 0.1172642 & -0.3058823 & 1 & & \\
\hline BOPO & -0.5086636 & -0.0423969 & 0.3073458 & -0.0104737 & 1 & \\
\hline $\begin{array}{c}\text { DCOVI } \\
\text { D }\end{array}$ & -0.0283328 & 0.14407604 & -0.0882644 & -0.1433688 & 0.04402344 & 1 \\
\hline
\end{tabular}

Tabel 9 . UJI HETEROSKEDASTISITAS

Dependent Variable: RESID1

Method: Panel Least Squares

Date: 06/17/21 Time: 22:18

Sample: 20192020

Periods included: 2

Cross-sections included: 21

Total panel (balanced) observations: 42

\begin{tabular}{crcrr}
\hline \hline \multicolumn{1}{c}{ Variable } & Coefficient & Std. Error & t-Statistic & Prob. \\
\hline \hline C & -0.003244 & 0.004445 & -0.729791 & 0.4702 \\
CAR & 0.000437 & 0.007405 & 0.058978 & 0.9533 \\
NPL & -0.015442 & 0.054737 & -0.282111 & 0.7795 \\
LDR & $-3.94 E-05$ & 0.002819 & -0.013992 & 0.9889 \\
BOPO & 0.003791 & 0.004129 & 0.918189 & 0.3646 \\
DCOVID & 0.000667 & 0.001316 & 0.506797 & 0.6154 \\
\hline \hline R-squared & 0.032927 & Mean dependent var & 0.000000 \\
Adjusted R-squared & 0.028388 & S.D. dependent var & 0.003897 \\
S.E. of regression & 0.004089 & Akaike info criterion & -8.029264 \\
Sum squared resid & 0.000602 & Schwarz criterion & -7.781025 \\
Log likelihood & 174.6145 & Hannan-Quinn criter. & -7.938275 \\
F-statistic & 0.345149 & Durbin-Watson stat & 2.247733 \\
Prob(F-statistic) & 0.009529 & & \\
\hline \hline
\end{tabular}


Seminar Nasional Hasil Penelitian dan Pengabdian Kepada Masyarakat 2021

Pengembangan Ekonomi Bangsa Melalui Inovasi Digital Hasil Penelitian dan

Pengabdian Kepada Masyarakat

Jakarta, 21 Oktober 2021

(halaman kosong) 